\title{
ГЕОГРАФІЯ РЕЛІГІЇ
}

Х.Хоффмманн ${ }^{*}$ (м. Краків, Польща)

\section{СВЯТОЕ МЕСТО КАК ПРЕДМЕТ ИЗУЧЕНИЯ ГЕОГРАФИИ РЕЛИГИИ}

География религии является одной из младших (но динамично развивающихся) областей религиоведческих исследований. Предмет её интересов - это взаимные связи, которые выступают между религией и географической средой. $\mathrm{C}$ одной стороны, исследуется влияние географической среды на формирование религиозных воображений, а с другой - обратная связь, то есть влияние какое оказывает религия на изменение географической среды. Кроме того, эта область религиоведения занимается распрастранением (или сокращением) отдельных религий, демографическо-статистическими вопросами, а также анализом топографии святых мест (hierotopografia), проблемами религиозных миграций (в том числе религиозного беженства), паломничества, миссий, религиозой туристики и т.п. [Jackowski A. Święta przestrzeń świata. Podstawy geografii religii.- Kraków, 2003.- S. 9-21].

В области анализа топографии святых мест можно заметить принцип, что всё, что обнаруживается в пейзаже как необыкновенное (благодаря своей величине, оригинальности, одинокости или недоступности), вызывает уважение или метафизический страх. Отдельной проблемой, тонко связаной с географией религии, являются вопросы: ботаники религии, географии табу, экологии религии и т.п.

Термин география религии использовал впервые английский писатель, учёный и врач сэр Thomas Brown в изданной в 1642 году в Лондоне работе «Religio Medici» [Jackowski A. Geografia religii. B: Religia. Encyklopedia PWN.- Warszawa, 2002.- T. 4.- S. 165-166]. Зато этнограф Oskar Ferdinand Peschel в работе «Völkerkunde» (Leipzig, 1874) первым

Хоффманн Х. - доктор філософії, професор Інституту релігієзнавства Ягеллонського університету (Краків, Польща). 
заметил, что все основатели религий происходят из чётко определённого пояса северной географической широты между десятым и сороковым градусом на азиатском континенте. Пояс этот он назвал «поясом основателей религий» (die Zone der Religionsstifter) [Margul T. Religia a przestrzeń i krajobraz. Kurs geografii religii dla studentów religioznawstwa i geografii.- Kraków, 1986.- S. 9].

К предшественникам географии религии надо причислить Paula Fickelera (статья «Grundfragen der Religionsgeographie» // Erdkunde, 1947.S. 121-144), а также Pierre Deffontaines'a - автора монографии «Géographie et religions» (Paris 1948). В дальнейшем серьёзный вклад в развитие молодой дисциплины внесли Gastone Imbrighi (Lineamenti di geografia religiosa. Studium.- Roma, 1961), Joachim-Friedrich Sprockoff (Zur Problematik einer Religionsgeographie.- München, 1963, а также многие его статьи в: Westermann Lexikon der Geographie. Band 1-4.- Braunschweig, 1969-1970) Heinz-Gerhard Zimpel (Vom Religionseinflu $\beta$ in den Kulturlandschaften zwischen Taurus und Sinaj // Relionsgeographie.- Hrsg. M. Schwind.- Darmstadt, 1975.- S. 254-321) и другие. Но истинно переломную роль сыграла работа Davida E. Sophera Geography of Religions (New York, 1967). К числу ведущих современно географов религии принадлежат: J.R. Al Fārūquī, Å.Hultkrantz - создатель так называемой экологии религии (Hultkrantz Å. Ecology of religon. Its Scope and Methodology // Science of Religion. Studies in Methodology. Proccedings of the Study Conference of the IAHR, Held in Turku, Finland 1973. Ed. by L. Honko. The Hague-Paris-New York, 1979.- P. 221-298) a также Manfred Büttner (Von der Religionsgeographie der Geisteshaltung.... // Die Erde, 1976.- №4.- S. 300329). D.E. Sopher в соавторстве с J.R. Al Fārūqū̄ издали «Historical Atlas of the Religions of the World» (London, 1974). В бывшем Советском Союзе новаторские работы обсуждаемого периода писал Павел Иванович Пучков (Современная география религий.- М., 1975). В Польше к предшественникам этой новой научной дисциплины принадлежат сравнительный религиовед Тадеуш Маргуль и географ Антони Яцковский. География религий развивается также в Германии, Франции, Словакии, в Северной Америке, Индии и Японии. С 1976 г. при Международном Географическом Союзе создано International Working Group on the Geography of Belief Systems, a c 1985 г. в Bohum (Германия) издается редактированный M.Büttnera и G.Rinschede специализированный журнал «Geographia Religionum» [Margul T. Op. cit.S. 9-13; Mikoś K. Geografia religii w perspektywie historycznej // Studia Religiologica.- 1988.- Z. 19.- S. 49-67; Jackowski A. Op. cit.].

Одним из важнейших понятий географии религии является 
категория «святое место». В феноменологическом подходе это пространство (святое или светское) с сакральными чертами, связанное какой-то сверхъестественной (нечеловеческой или сверхчеловеческой) силой. Как таковое, оно доступно обычному испытанию в небольшой степени или вообще недоступно. Появляется, в свою очередь, в специфических условиях и ситуациях так называемого сакрального времени (праздника).

Расположение святого места является результатом испытания этой силы, или заключается в приписывании месту чрезвычайного характера (то есть «назначенного силой»). Стоит подчеркнуть, что это не обозначает того, что святое место обязательно (хотя, часто так и бывает) отличается другой физикой. Суть святого места характеризует разный по значению и светскому поведению способ принимать его как часть пространства. С религиозной точки зрения основанием святых мест является иерофания (феофания). Констатация того или иного места как места святого нередко связывается с чудодейственностью, переживанием чуда. Так, убежденность в чудодейственности святых мест, в их специфической близости по отношению к миру силы, божественного или Бога бывает причиной приношения жертв и даров (например, даров на алтарь) [Miejsca święte. Leksykon. Pod. red. Z. Paska.- Kraków, 1997; Maciuszko J.T. Miejsce święte // Religia. Encyklopedia PWN.- Warszawa, 2003.- T. 7.- S. 165-166].

Святые места могут остаться в натуральном состоянии (реки, озёра, горы, пещеры, деревья, рощи и т.п.) или могут быть изменены человеком (храмы). Частой закономерностью является и то, что святые места почитаются разными народами и религиями (по принципу Santa Maria sopra Minerva). Завоеватели, колонизаторы территорий «принимали» святые места от людей, от покоренных народов, которые жили на них ранее, но они, однако, давали им свою интерпретацию интерпретацию, в соответствии своим культам и согласно своим верованиям. Не удивляет в таком случае и тот факт, что многие христианские святые места (церкви, монастыри) создавались на местах, где раньше (часто очень долго) действовали языческие, дохристианские местные культы.

Cвятые места зачастую считали центром мира (греч. omphalós) или осью мира (axis mundi). Архетипными примерами святых мест являются определённые общественные организмы, например государства, города или по семейной шкале дом. Относительно государств их святость особенно подчёркивается в народных религиях [Mensching G. Soziologie der Religion.- Bonn, 1947; Glasenapp H. Religie 
102

niechrześcijańskie.- Warszawa, 1966.- S. 290].

Города чаще всего своё значение получили благодаря близости к святым местам, которые со временем стали святилищами и свою святость получили благодаря тому, что по верованиям соединят отдельные космические сферы (axis mundi).

По шкале семьи космической осью (axis mundi) и архитепной картиной святого места является дом. Вход (порог и дверь) отделяет освящённое пространство внешнего мира и упорядочивает его. Домашний очаг часто становит перенесение идеи центра святого места (omphalós) в шкалу семейной жизни. Является он не только объектом культа, но также местом совершения обряда в семейном и личном культе. Такой характер культа дома как святого места подтверждает например римский культ ларов и пенатов, которые по необходимости могут быть перенесены и устанавливать святое место в новом месте жительства [Maciuszko J.T. Op. cit.- S. 166].

У cвятых мест своя, своеобразная для данной религиозной традиции, структура. Она обнаруживается например в организации культа и способа участвовать в нём. Организация пространства культа, как правило, не должна быть очевидно однородной для всех участников культа. Часто отделяются сферы, оговорённые для разных групп священников или посвящённых. На их территории могут действовать многие законы табуистического характера (табу); структура может быть также непосредственно связана с видом литургической и обрядовой жизни, подробными пурификационными правилами. Типичными примерами являются синтоистские святилища в Японии или Иерусалимский храм.

Сакральный характер святых мест подтверждает подход к ним, как к месту убежища (греч. ásylon), что обозначает то ли изъятие их из светского порядка, то ли мнение, что беженец в распоряжении оценки сил, присутствующих на святом месте.

Вера в чудесный характер святых мест является причиной того, что в них особенно сильно верные желают отдавать почёт (жертвоприношение, молитва) сверхъестественным силам, считая, что их близость облегчит приобретение специфических религиозных благ (милость, отпущение грехов) или важных для жизни (например, здоровье). Поэтому святые места являются часто целью индивидуальных или массовых паломничеств и играют очень важную культурную и политическую роль.

Паломничество - это индивидуальное или групповое путешествие к освящённому данной религиозной традицией месту. 
Паломничество к святым и чудесным местам, которые имеют особое значение для прихожан встречается очень часто в иудаизме, исламе, христианстве, а также в индуизме (jatra) и буддизме.

По мнению Юзефа Баняка, географию паломнического движения определяют два фактора - горизонтальный и вертикальный. Горизонтальный фактор связан с территориальным радиусом паломничества к отдельным центрам. Зато вертикальный фактор связан с религиозными или народными и общественными надеждами паломников. Принимая во внимание эти факторы, паломнические центры можно разделить на: общегосударственные, региональные, местные и приходские. К местным центрам паломничают чаще всего прихожане из недалёких окрестностей. Например, в польском католицизме к приходским центрам паломничают прихожане из окружающих местностей, чаще всего по случаю храмовых праздников и торжеств связанных с культом святых и покровителей.

Сила и радиус влияния на паломников являются основными факторами различающими места и центры паломничества в каждой стране. Их популярность зависит, между прочим, от их истории, обустройства, вида и качества требы, формы религиозного культа, географического расположения, условий транспортных связей в районе, лёгкости расквартирования и организации питания. При этом самыми важными являются всё-таки религиозные факторы и формы пастырства, часто соединённые с умелой стратегией маркетинга и системы торговли предметами культового назначения [Baniak J. Pielgrzymka // Religia. Encyklopedia PWN.- Warszawa, 2003.- T. 8.- S. 105-108].

Паломнический центр своё значение получает из убеждения прихожан о святости места, к которому они прибывают. На практике это разные формы культа: реликвии, картины, фигуры, станции тернистого пути, источники воды и т.п. Паломничества влияют на религиозную жизнь паломников в трёх основных сферах: а) религиозного сознания, б) религиозных практик и в) моральной жизни. Пребывание паломников в паломническом центре углубляет их религиозное сознание, развязывает много религиозных переживаний и испытаний, которые эмоционально связывают их с данным святилищем. Однако влияние паломничества сильнее всего отражается на выполнении религиозных обрядов, которые получают благодаря этому свою жизненную значимость [Baniak J. dz. cyt.].

Как пишет А.Яцковский, в паломничествах к святым местам в мире участвует около трёхсот миллионов человек в год, из них почти 200 миллионов составляют христиане, 30 миллионов - индуисты, около 40 
миллионов это исповедующие ислам и буддизм, около 30 миллионов исповедующих другие религии. Среди христианских паломников свыше 80 миллионов (40\%) паломничают в 20 главных центров паломничества этой религии. Как пример можно привести Рим (Ватикан) и Гваделупу (в каждое из этих мест паломничают по 12 миллионов человек), СанДжованни-Ротондо (7 миллионов), Лурд (6 миллионов), Фатиму (5 миллионов), Ченстохов (4 миллиона). В остальных религиях такими центрами являются, к примеру, в индуизме Аллахабад (12 миллионов) и Варанаси (10 миллионов), в исламе Мекка (5 миллионов). Специфическим паломническим центром является Иерусалим - святой город для исповедующих три религии - иудаизм, христианство и ислам. Из-за политической обстановки на Ближнем Востоке этот город каждый год посещают лишь не более 100 тысяч человек [Jackowski A. Święta przestrzeń świata. Op. cit.- S. 131-132; Jackowski A. Zarys geografii pielgrzymek.- Kraków, 1981; Jackowski A. Pielgrzymowanie.- Wrocław, 1998].

Как вытекает из представленных выше размышлений, география религии является очень важным дополнением к историческим исследованиям, так как в центре её внимания находится пространство вторая наряду со временем философская и религиоведческая категория. 